\title{
Stimulation of $\left[26-{ }^{14} \mathrm{C}\right]$ cholesterol oxidation by ascorbic acid in scorbutic guinea-pigs
}

\author{
BY E. GINTER, R. NEMEC AND P. BOBEK \\ Research Institute of Human Nutrition, Bratislava, Czechoslovakia
}

(Received I3 September 1971 - Accepted 8 March 1972 )

\begin{abstract}
I. Oxidation of intraperitoneally injected [26- $\left.{ }^{14} \mathrm{C}\right]$ cholesterol to ${ }^{14} \mathrm{CO}_{\mathrm{g}}$ was significantly increased after resaturation of vitamin $\mathrm{C}$-deficient guinea-pigs with one injection of $100 \mathrm{mg}$ ascorbic acid and subsequent peroral administration of $50 \mathrm{mg}$ ascorbic acid per animal per $\mathrm{d}$.

2. Stimulation of cholesterol oxidation was observed in resaturated guinea-pigs either fed ad lib. or pair-fed.

3. A highly significant direct correlation was found between ascorbic acid concentration in liver and rate of cholesterol oxidation.
\end{abstract}

A hepatic accumulation of cholesterol occurs in male guinea-pigs with chronic ascorbic acid deficiency. If guinea-pigs are given an atherogenic cholesterol-containing diet, chronic hypovitaminosis $\mathrm{C}$ causes an increased accumulation of total cholesterol in many tissues, including the thoracic aorta (Ginter, Babala \& Červeň, I969; Ginter, 1970). In experiments with two kinds of labelled cholesterol we have found that the cause of an increased cholesterol accumulation in tissues of hypovitaminotic animals was retarded catabolism of cholesterol to bile acids. Thus, hypovitaminotic animals dosed with $\left[4^{-14} \mathrm{C}\right]$ cholesterol excreted smaller amounts of faecal ${ }^{14} \mathrm{C}$-bile acids, and in the bile acid fraction of their liver and gall-bladder bile significantly less ${ }^{14} \mathrm{C}$ was found than in that of the control group. Oxidation of $\left[26-{ }^{14} \mathrm{C}\right]$ cholesterol to ${ }^{14} \mathrm{CO}_{2}$ was significantly decreased in guinea-pigs with chronic ascorbic acid deficiency (Ginter, Cerveň, Nemec \& Mikuš, I97r).

The aim of the present work was to examine whether resaturation of vitamin Cdeficient guinea-pigs with high doses of ascorbic acid increases significantly cholesterol catabolism.

\section{EXPERIMENTAL}

\section{Animals and experimental design}

Eighteen male guinea-pigs initially weighing about $480 \mathrm{~g}$ were fed $a d$ lib. on a scorbutogenic diet (Ginter, Ondreička, Bobek \& Šmko, 1969). After $16 \mathrm{~d}$ they were divided into three groups, each of six animals. The first group was kept on the scorbutogenic regimen. Animals in the remaining two groups were given an intraperitoneal injection of $100 \mathrm{mg}$ ascorbic acid per animal on the I6th day, and from then on they were given. perorally $50 \mathrm{mg}$ ascorbic acid per animal per $\mathrm{d}$. On the $\mathrm{x} 7$ th day after the scorbutogenic regimen started, all animals were given intraperitoneally a solution of $\left[26-{ }^{14} \mathrm{C}\right]$ cholesterol (Radiochemical Centre, Amersham, England; specific activity $24 \mathrm{mCi} / \mathrm{mmol}$ ) in a dose of $0.70-0.75 \mu \mathrm{Ci} / 100 \mathrm{~g}$ body-weight. The labelled cholesterol was dissolved in methanol containing Tween 20 , the methanol was evaporated and the residue was redissolved in sterile physiological saline. 
The guinea-pigs were individually placed in metabolic cages of diameter $29 \mathrm{~cm}$. Air, free of $\mathrm{CO}_{2}$, was admitted to the cages and aspirated at a rate of $400-600 \mathrm{ml} / \mathrm{min}$ and bubbled into two washing bottles with fritted-glass stoppers filled with $2 \cdot 5 \mathrm{M}-$ aqueous $\mathrm{KOH}$. Expired $\mathrm{CO}_{2}$ was collected for successive $24 \mathrm{~h}$ periods during the next ro d. In this period vitamin C-deficient guinea-pigs had free access to food. Some of the resaturated animals were given a scorbutogenic diet ad lib.; the other group was pair-fed with the deficient guinea-pigs, in which food consumption was markedly reduced (on the $\mathrm{I} 8$ th day of avitaminosis $\mathrm{C}$ about $20 \mathrm{~g}$ of food per animal per $\mathrm{d}$; on the 23 rd day about Io $g$ per animal per $\mathrm{d}$; in the last $2 \mathrm{~d}$ of the experiment scorbutic guinea-pigs totally refused food). On the 27 th day from the beginning of the scorbutogenic regimen the guinea-pigs were killed by decapitation.

\section{Analytical methods}

Ascorbic acid in tissues was determined after extraction in $6 \%(\mathrm{w} / \mathrm{v})$ trichloroacetic acid (Roe \& Kuether, 1943). Total cholesterol was determined manually after extraction (Folch, Lees \& Stanley, 1957) by the Liebermann - Burchard reaction (Cook, I958). Samples of blood serum and liver were dissolved in Nuclear Chicago Solubilizer for determination of total ${ }^{14} \mathrm{C}$ activity. A known quantity of the $\mathrm{KOH}$ solution containing dissolved ${ }^{14} \mathrm{CO}_{2}$ was acidified and ${ }^{14} \mathrm{CO}_{2}$ was absorbed into ethanolamine in an apparatus described by Saba \& Di Luzio (I966). Radioactivity of ${ }^{14} \mathrm{C}$ samples was assayed in toluene-based scintillator in a Nuclear Chicago liquid-scintillation spectrometer (model Mark I) using an external standard to correct for quenching. The results were statistically evaluated by Student's $t$ test, and correlations were determined by the method of least squares.

\section{RESULTS}

Fig. I shows the weight changes of the experimental groups, Body-weights of vitamin C-deficient guinea-pigs began to decrease at about the 18 th day after the scorbutogenic regimen started. The weight curve of the resaturated pair-fed guinea-pigs (one animal died as a result of an accident) was almost identical with that for the vitamin C-deficient animals. Weights of resaturated guinea-pigs fed ad lib. increased a little during the experiment.

Table $\mathrm{I}$ gives the ascorbic acid concentrations and total cholesterol concentrations in tissues of guinea-pigs of all groups. Ascorbic acid concentrations in tissues of avitaminotic guinea-pigs were very low; resaturation with high doses of ascorbic acid caused a significant increase in the concentrations; the concentrations in the guinea-pigs fed ad lib. were significantly higher than those in the pair-fed resaturated group. This phenomenon might have been caused by an increased decomposition of ascorbic acid in the pair-fed group, which was underfed and during the last $2 \mathrm{~d}$ of the experiment completely starving. Total cholesterol concentrations in tissues of guinea-pigs from the individual groups did not differ significantly. Cholesterol concentrations in blood serum of the resaturated pair-fed group were significantly increased.

In Table 2 total ${ }^{14} \mathrm{C}$ activity and specific activity of blood serum and liver cholesterol are presented. In agreement with results on total cholesterol concentrations (Table $\mathrm{r}$ ), 
Vol. 28

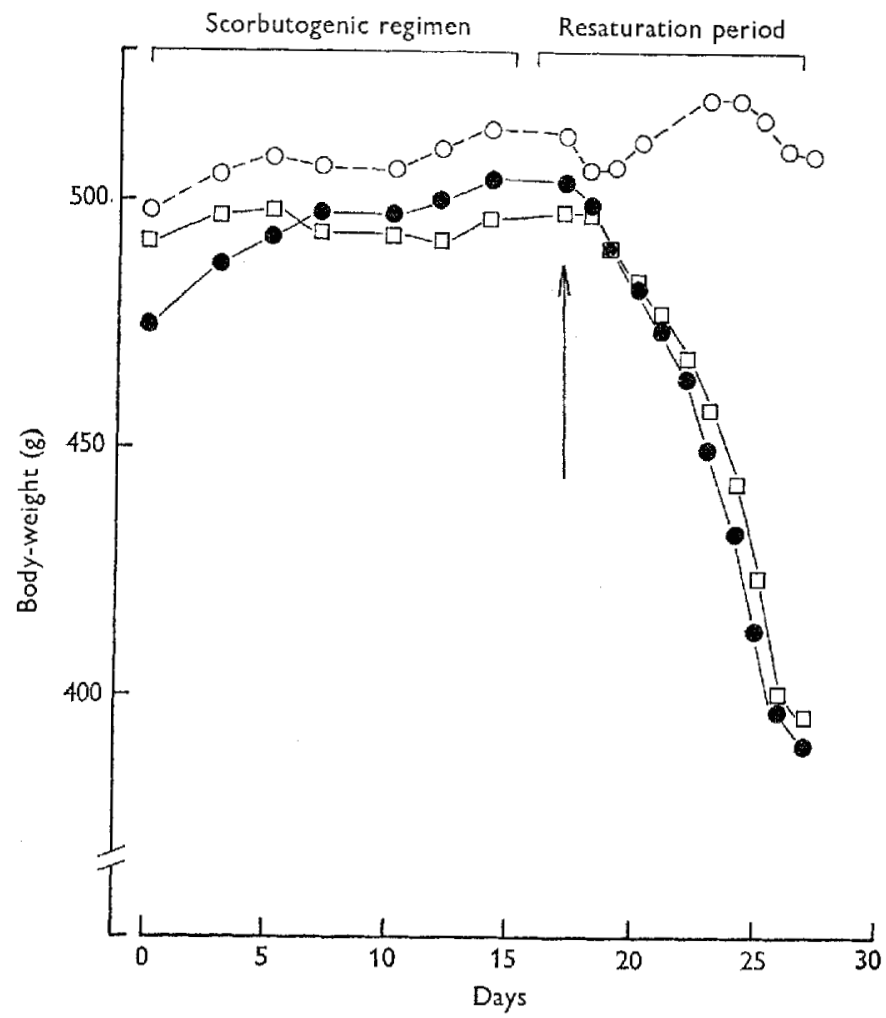

Fig. I. Weight curves of vitamin C-deficient (-), six animals), resaturated pair-fed ( $\square-[]$, five animals) and resaturated $a d l i b .-f e d,(0--0$, six animals) guinea-pigs. The arrow indicates the day of injection of all groups with $\left[26-{ }^{11} \mathrm{C}\right]$ cholesterol.

Table I. Mean walues with their standard errors for ascorbic acid and cholesterol concentrations in the tissues of vitamin $C$-deficient and resaturated guinea-pigs

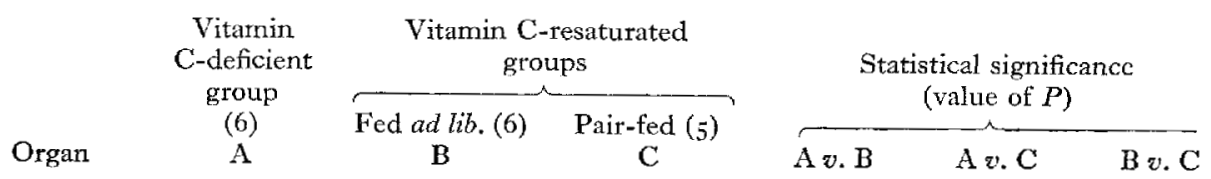

\begin{tabular}{|c|c|c|c|c|c|c|}
\hline & & & & & & \\
\hline Liver & $0.45 \pm 0.23$ & Ir.06 0.49 & $6.72 \pm 0.51$ & $<0.001$ & $<0.001$ & $<0.00 \mathrm{I}$ \\
\hline Adrenals & $x \cdot 37 \pm 0.73$ & $87 \cdot 3^{8} \pm 7 \cdot 93$ & $45.91 \pm 2.25$ & $<0.00 \mathrm{I}$ & $<0.00 I$ & $<0.002$ \\
\hline Small intestine & $I \cdot I 3 \pm 0.26$ & $I 8 \cdot 95 \pm 1 \cdot 45$ & $I 3 \cdot 3 I \pm I \cdot 34$ & $<0.001$ & $<0.001$ & $<0.05$ \\
\hline Spleen & $0.99 \pm 0.15$ & $31 \cdot 07 \pm 0.98$ & $23.53 \pm 0.76$ & $<0.001$ & $<0.001$ & $<0.001$ \\
\hline \multicolumn{7}{|c|}{ Total cholesterol (mg/I00 g or / $100 \mathrm{ml}$ ) } \\
\hline Liver & $464 \pm 6 I$ & $409 \pm 35$ & $640 \pm 133$ & NS & NS & NS \\
\hline Adrenals & $4459 \pm 598$ & $4453 \pm 977$ & $5279 \pm 604$ & NS & NS & $\mathrm{NS}$ \\
\hline Small intestine & $34^{8} \pm 47$ & $302 \pm 14$ & $275 \pm 23$ & NS & NS & $\mathrm{NS}$ \\
\hline Blood serum & $105 \pm 13$ & $90 \pm 9$ & $170 \pm 14$ & NS & $<0.0 T$ & $<0.001$ \\
\hline
\end{tabular}

Figures in parentheses are the numbers in the groups at the end of the experiment. NS, not significant $(P>0.05)$. 
Table 2. Mean values with their standard errors for total ${ }^{14} \mathrm{C}$ activities and specific activities of cholesterol in the blood serum and liver of vitamin C-deficient and resaturated guinea-pigs

\begin{tabular}{|c|c|c|c|c|c|c|}
\hline \multirow[b]{2}{*}{ Organ } & \multirow{2}{*}{$\begin{array}{c}\text { Vitamin C- } \\
\text { deficient } \\
\text { group } \\
(6) \\
\text { A }\end{array}$} & \multicolumn{2}{|c|}{$\begin{array}{c}\text { Vitamin C-resaturated } \\
\text { groups }\end{array}$} & \multicolumn{3}{|c|}{$\begin{array}{l}\text { Statistical significance } \\
\text { (value of } P \text { ) }\end{array}$} \\
\hline & & $\begin{array}{c}\text { Fed } a d l i b .(6) \\
\mathbf{B}\end{array}$ & $\begin{array}{c}\text { Pair-fed (5) } \\
\mathrm{C}\end{array}$ & $A v \cdot B$ & $\mathrm{~A} v . \mathrm{C}$ & $\mathrm{B} v \cdot \mathrm{C}$ \\
\hline \multicolumn{7}{|c|}{ Total activity (disintegrations/min per $\mathrm{g}$ wet tissue) } \\
\hline d serum & $\begin{array}{r}8398 \pm 1292 \\
27175 \pm 2076\end{array}$ & $\begin{array}{r}6380 \pm \text { I I } 45 \\
27890 \pm 4976\end{array}$ & $\begin{array}{l}13063 \pm 1647 \\
46197 \pm 5683\end{array}$ & $\begin{array}{l}\text { NS } \\
\text { NS }\end{array}$ & $\begin{array}{l}<0.05 \\
<0.01\end{array}$ & $\begin{array}{l}<0.01 \\
<0.05\end{array}$ \\
\hline \multicolumn{7}{|c|}{ Specific activity (disintegrations/min per $\mathrm{mg}$ total cholesterol) } \\
\hline rum & $\begin{array}{l}7784 \pm 914 \\
6199 \pm 633\end{array}$ & $\begin{array}{l}708 \mathrm{r} \pm 87 \mathrm{x} \\
68 \mathrm{x} 6 \pm \mathrm{II04}\end{array}$ & $\begin{array}{l}8142 \pm x 662 \\
7950 \pm x 197\end{array}$ & $\begin{array}{l}\text { NS } \\
\text { NS }\end{array}$ & $\begin{array}{l}\text { NS } \\
\text { NS }\end{array}$ & $\begin{array}{l}\text { NS } \\
\text { NS }\end{array}$ \\
\hline
\end{tabular}

Figures in parentheses are the numbers in the groups at the end of the experiment.

NS, not significant $(P>0.05)$.

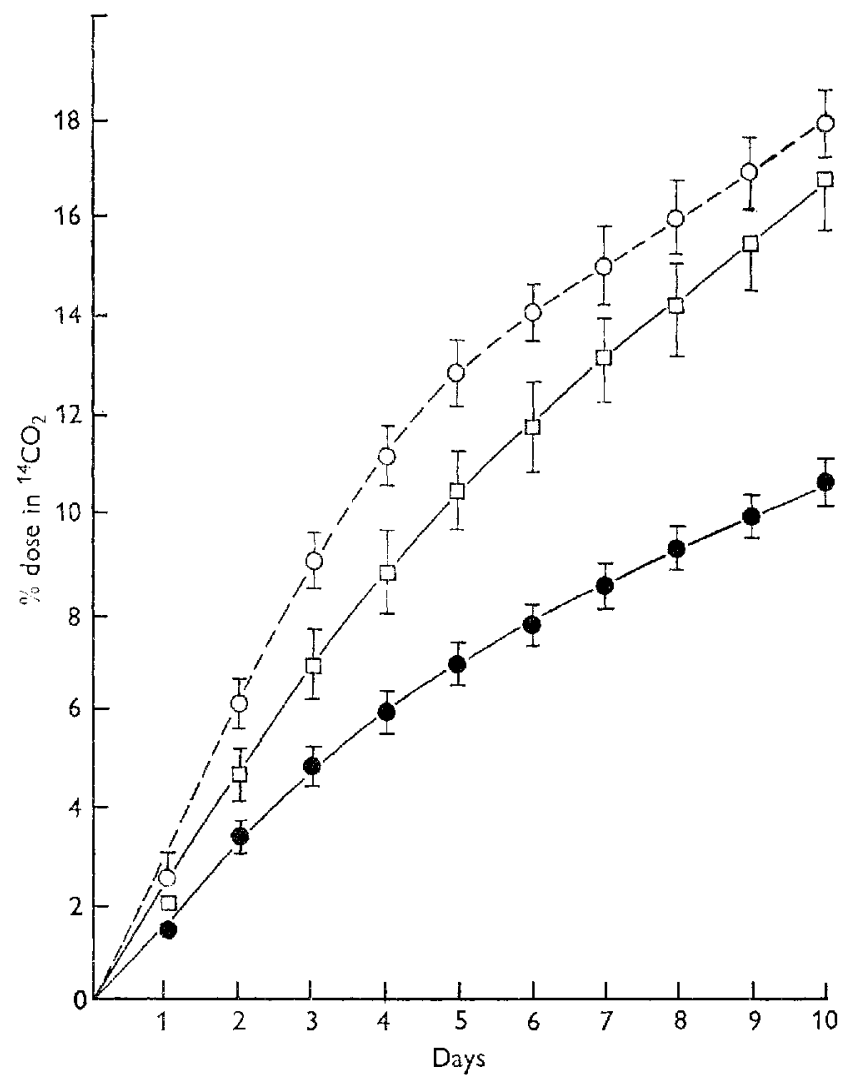

Fig. 2. Oxidation of $\left[26{ }^{14} \mathrm{C}\right]$ cholesterol to ${ }^{14} \mathrm{CO}_{2}$ as percentage of the dose injected in vitamin C-deficient (- six animals), resaturated pair-fed ( $\square-\square$, five animals) and resaturated ad lib.-fed (O---O, six animals) guinea-pigs. The vertical bars represent the standard errors of the mean. 


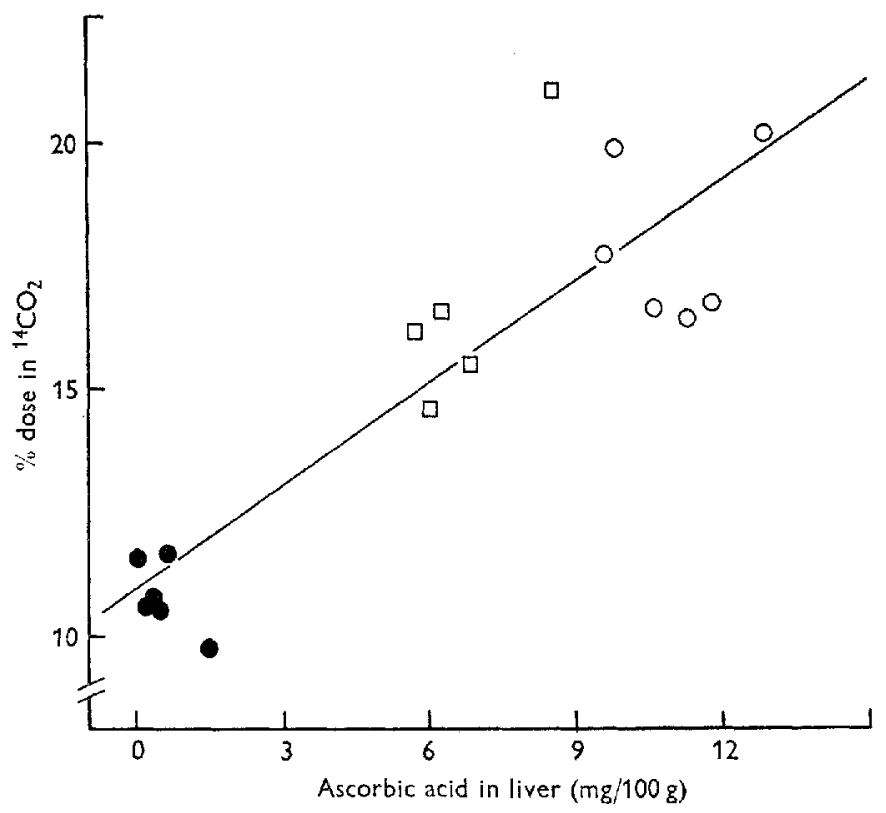

Fig. 3. Linear direct correlation $(P<0.001)$ between ascorbic acid concentration in liver and percentage of $\left[26-{ }^{14} \mathrm{C}\right]$ cholesterol oxidized to ${ }^{14} \mathrm{CO}_{2}$ within $\mathrm{rod}$, in vitamin $\mathrm{C}$-deficient (e), resaturated pair-fed $(\square)$ and resaturated $a d$ lib.-fed $(O)$ guinea-pigs.

the total ${ }^{14} \mathrm{C}$ activity in blood serum of pair-fed resaturated guinea-pigs was significantly increased. There were no significant differences between resaturated ad lib.-fed and vitamin C-deficient animals. We have found that, in guinea-pigs given $\left[26-{ }^{14} \mathrm{C}\right]-$ cholesterol, incorporation of label into digitonin-precipitable sterols is practically identical with the total ${ }^{14} \mathrm{C}$ activity of blood serum and liver tissue (Bobek, Ginter \& Cerveň, I971). This allows calculation of the specific activity of cholesterol from the values for total ${ }^{14} \mathrm{C}$ activity and cholesterol concentration. The values obtained in such a way were very similar for blood serum and liver and for all three experimental groups.

Fig. 2 shows production of ${ }^{14} \mathrm{CO}_{2}$ cumulatively within ro $\mathrm{d}$ of $\left[26-{ }^{14} \mathrm{C}\right]$ cholesterol administration. The time-course of the curves confirms an accelerated oxidation of labelled cholesterol in both groups resaturated with high doses of ascorbic acid. The difference in the amount of expired ${ }^{14} \mathrm{CO}_{2}$ between the vitamin $\mathrm{C}$-deficient group and the resaturated ad lib.-fed group was significant from the Ist day (ist day $P<0.05$, 2nd day $P<0.0$, all remaining intervals $P<0.00$ ), between the vitamin $\mathrm{C}$-deficient and the resaturated pair-fed group from the and day of the experiment (2nd day $P<0.05,3^{\text {rd }-5 \text { th }}$ day $P<0.02-0.0$ r, all remaining intervals $\left.P<0.001\right)$. [26- $\left.{ }^{14} \mathrm{C}\right]$ cholesterol oxidation in the pair-fed groups slightly decreased when compared with that of the $a d l i b$.-fed group; however, this difference was significant only between the $3^{\text {rd }}$ and the 6 th day of the experiment $(P<0.05)$.

As most of the cholesterol is probably catabolized in the liver, we have correlated the percentage of $\left[26-{ }^{14} \mathrm{C}\right]$ cholesterol oxidized to ${ }^{14} \mathrm{CO}_{2}$ in Io $\mathrm{d}$ with the ascorbic acid concentration in liver for all three groups. Results are presented in Fig. 3 and they show a very close correlation between these two measurements $(P<0.00 \mathrm{r})$. 
From the values for the specific activities of blood serum or liver cholesterol and from the amount of ${ }^{14} \mathrm{CO}_{2}$ excreted during the $24 \mathrm{~h}$ period before the animals were killed, the rate of cholesterol breakdown was calculated according to the method of Myant \& Lewis (Ig66). In the vitamin C-deficient group the mean value was about $8 \mathrm{mg}$ cholesterol per animal per $\mathrm{d}$, in the resaturated ad lib.-fed group about $14 \mathrm{mg}$ per animal per $\mathrm{d}$, and in the resaturated pair-fed group about $\mathrm{I} 7 \mathrm{mg}$ per animal per $d$. These values are only approximate, as isotopic equilibrium was probably not achieved and the results for cholesterol turnover to bile acids obtained by the $\left[{ }^{26-14} \mathrm{C}\right]$ cholesterol method are underestimated (Chevallier \& Lutton, I966).

\section{DISCUSSION}

Oxidation of the side-chain of cholesterol is implicated in the synthesis of bile acids which play the quantitatively most important part in the elimination of cholesterol from the body. Results obtained from this study together with our demonstration of retarded transformation of $\left[4^{-14} \mathrm{C}\right]$ cholesterol to bile acids and decreased $\left[26-{ }^{14} \mathrm{C}\right]$ cholesterol oxidation to ${ }^{14} \mathrm{CO}_{2}$ in guinea-pigs with latent chronic vitamin $\mathrm{C}$ deficiency (Ginter et al. 1971) suggest that ascorbic acid plays an important part in this catabolic process. In this connexion, it is already known that ascorbic acid stimulates 7 -dehydrocholesterol oxidation in vitro (Kandutsch, I966) and cholesterol transformation to bile acids in liver mitochondria from scorbutic guinea-pigs (Guchhait, Guha \& Ganguli, 1963). Shimizu (1970) demonstrated stimulation of the cholesterol side-chain cleavage reaction in bovine and porcine adrenal mitochondrial preparations by low concentrations of ascorbic acid. The hypocholesterolemic effect of ascorbic acid observed by some authors in humans (Myasnikova, I947; Ginter, Kajaba \& Nizner, 1970; Spittle, 1971) is probably connected with the stimulation of cholesterol oxidation described in this work.

When bile acids are formed in the liver by the degradation of the cholesterol sidechain, the three terminal carbon atoms are removed as propionyl-CoA (Suld, Staple \& Gurin, 1962), which is quickly oxidized to $\mathrm{CO}_{2}$. It is improbable that labelled intermediates from oxidized $\left[26-{ }^{14} \mathrm{C}\right]$ cholesterol accumulate during the period allowed for partial equilibration and that resaturation by vitamin $\mathrm{C}$ increases the excretion of ${ }^{14} \mathrm{CO}_{2}$ merely by causing a 'sweeping out' of labelled pools. In some experimental animals total ${ }^{14} \mathrm{C}$ activity in tissues was compared with the activity of the digitoninprecipitable fraction. Nearly all the ${ }^{14} \mathrm{C}$ activity was found in the digitonin-precipitable fraction. It would seem that, under our conditions, there is no significant accumulation of metabolites of the propionyl fragment.

Ascorbic acid is an important cofactor in the hydroxylation of many substances, for example proline, aromatic amino acids, tryptophan and dopamine. It is therefore possible that vitamin $\mathrm{C}$ stimulates also the hydroxylation reactions of cholesterol, by means of which cholesterol is transformed to bile acids in the liver. The mechanism of ascorbic acid intervention in cholesterol catabolism remains an open question. 


\section{REFERENCES}

Bobek, P., Ginter, E. \& Cerveň, J. (I97I). Physiologia bohemoslov. 20, 523.

Chcvallier, F. \& Lutton, C. (Ig66). Bull. Soc. Chim. biol. 48, 295.

Cook, R. P. (1958). Cholesterol p. 487. New York: Academic Press.

Folch, J., Lees, M. \& Stanley, G. H. S. (I957). J. biol. Chem. 226, 497.

Ginter, E. (1970). Biol. Práce 16, no. 6, p. I.

Ginter, E., Babala, J. \& Cerveň, J. (1969). F. Atheroscler. Res. ro, 341.

Ginter, E., Cerven̆, J., Nemec, R. \& Mikuš, L. (1971). Am. F. clin. Nutr. 24, 1238.

Ginter, E., Kajaba, I. \& Nizner, O. (1970). Nutr. Metabol. 12, 76.

Ginter, E., Ondrcička, R., Bobek, P. \& Simko, V. (1969). F. Nutr. 99, 26 I.

Guchhait, R., Guha, B. C. \& Ganguli, N. C. (1963). Biochem. F. 86, 193.

Kandutsch, A. A. (1966). F. Lipid Res. 7, 603.

Myant, N. B. \& Lewis, B. (I966). Clin. Sci. 30, II7.

Myasnikova, I. A. (1947). Trudy Voyennomorsk. med. akad., Leningrad 8, 140.

Roe, J. H. \& Kuether, C. A. (1943). 7. biol. Chem. r47, 399.

Saba, T. M. \& Di Luzio, N. R. (I966). Y. Lipid Res. 7, 566.

Shimizu, K. (1970). Biochim. biophys. Acta 210, 333 .

Spittle, C. R. (I97 I). Lancet ii, 1280.

Suld, H. M., Staple, E. \& Gurin, S. (1962). F. biol. Chem. 237, 338, 